\title{
Marketed under New Drug Application
}

National Cancer Institute

\section{Source}

National Cancer Institute. Marketed under New Drug Application. NCI Thesaurus. Code C73594.

A category specifying that a product is marketed under a New Drug Application. 